\title{
Aggregates morphometry of a Inceptisol under conservationist system ${ }^{1}$
}

\section{Morfometria de agregados de um Cambissolo sob manejo conservacionista}

\section{Érika Andressa da Silva ${ }^{2 *}$; Geraldo César de Oliveira ${ }^{3}$; Carla Eloize Carducci4; Bruno Montoani Silva ${ }^{5}$ Milson Evaldo Serafim ${ }^{6}$}

\begin{abstract}
Morphological characteristics of the soil aggregates are important tools to analyzing and monitoring the structural quality. The present study aimed to characterize morphometrically aggregates of a Inceptisol, originated from pelitic rocks, after 1.5 years of the implementation of a management system that adopts conservation tillage practices in the coffee cultivation. The aggregates were collected at the depths of $0.0-0.05 ; 0.05-0.20 ; 0.20-0.40 ; 0.40-0.80 \mathrm{~m}$, both at row and interrow position in a coffee field, and also a natural environment of native vegetation that was used as a reference for the study. The analyzes of the aggregates were carried through 2D images obtained by scanning at 300 dpi spatial resolution. Each image contained 60 households and were processed using the software QUANTPORO. The morphometric variables were obtained: area, perimeter, compactness, roughness, appearance and Ferret diameter. For validation, the correlations among morphometric variables determined by image analysis and pattern aggregation indices (GMD, MWD and aggregates retained in the class $>2.00 \mathrm{~mm}$ ) obtained by wet sieving were studied. After 1.5 years of implantation increased the dimensions of the aggregates on the natural environment have been detected, as well as better structural quality Inceptisol. Key words: Image analysis. Morphometric characteristics of the aggregates. Structural quality.
\end{abstract}

\section{Resumo}

As características morfológicas dos agregados são importantes indicadores da qualidade estrutural do solo. O presente trabalho teve por objetivo caracterizar morfometricamente os agregados de um Cambissolo originado de rochas pelíticas (siltito) após 1,5 anos da implantação de um sistema de manejo que adota práticas conservacionistas do solo no cultivo do cafeeiro. Os agregados foram coletados nas profundidades de $0,0-0,05 ; 0,05-0,20 ; 0,20-0,40 ; 0,40-0,80 \mathrm{~m}$, nas posições linha e entrelinha do cafeeiro e também em um ambiente natural Cerrado Nativo tomado como referência para o estudo. As análises dos agregados foram realizadas por meio de imagens 2D obtidas por escaneamento, em 300 dpi de resolução espacial. Cada imagem continha 60 agregados e foram processadas utilizando o software Quantporo. As variáveis morfométricas obtidas foram: área, perímetro, compacidade, rugosidade, aspecto e diâmetro de Ferret. Para validação, foram estudadas as correlações entre as variáveis

${ }^{1}$ Parte da Dissertação do primeiro autor. Trabalho financiado pelos órgãos CNPq e FAPEMIG.

${ }^{2}$ Prof ${ }^{a}$ Substituta de Física e Conservação do Solo e Água e Doutoranda em Ciência do Solo, Universidade Federal de Lavras, Departamento de Ciência do Solo, DCS/UFLA, Lavras, MG. Bolsista Fapemig, Brasil. E-mail: erika.silva@dcs.ufla.br

3 Prof. Associado, DCS/UFLA, Lavras, MG, Bolsista CNPq. Brasil. E-mail: geraldooliveira@dcs.ufla.br

${ }^{4}$ Prof ${ }^{a}$ Auxiliar, Universidade Federal de Santa Catarina, UFSC, Campus Curitibanos, SC, Brasil. E-mail: ec.carducci@ufsc.br

5 Prof. Adjunto, Universidade Federal de São João Del Rei, UFSJ, Campus Sete Lagoas, MG, Brasil. E-mail: montoani@gmail. com

${ }^{6}$ Prof., Instituto Federal de Educação, Ciência e Tecnologia de Mato Grosso, Cáceres, MT, Brasil. E-mail: milson.serafim@cas. ifmt.edu.br

* Author for correspondence 
morfométricas determinadas pela análise de imagem e dos índices de agregação padrão (DMG, DMP e agregados retidos na classe $>2,00 \mathrm{~mm}$ ) obtidos por tamisamento úmido. Após 1,5 anos de implantação do sistema de manejo foram detectados aumento nas dimensões dos agregados em relação ao ambiente natural, assim como melhor qualidade estrutural do Cambissolo.

Palavras-chave: Análise de imagens. Características morfométricas dos agregados. Qualidade estrutural.

\section{Introduction}

Quantifying aggregate geometry through 2D imaging became possible by modifications in software used to measure leaf diseases, generating the Quantoporo software for soil aggregate studies (VIANA et al., 2004). The technique was named as micro-morphometry, since methodology is derived from phytopathology, in which studies are performed in microscopic scale (CARVALHO et al., 2010; CREMON et al., 2009; SOUZA et al., 2012). In this paper, we used the term morphometry, once the images have both macro and micrometric dimensions.

In Brazil, morphometry and/or micromorphometry are new research lines with few studies (CARVALHO et al., 2010; CREMON et al., 2009, 2011; OLSZEVSKI et al., 2004; SOUZA et al., 2012; VIANA et al., 2004). In these studies, authors have been supporting that morphometric features have relationships with other physicochemical and hydric attributes of soil, and can be used as indicators of farming soil structure quality.

Aggregate geometry (form, size and position) interfere in pore diameter distribution, what might change air, water and nutrient dynamics within the soil and, consequently, affecting plant root growth (CREMON et al., 2011; VIANA et al., 2004).

Overall, based on aggregate morphometric characterization, it has been reported that soil management using agricultural gypsum and practices to enhance soil organic matter content promote increase in aggregate area (CREMON et al., 2011; OLSZEVSKI et al., 2004; SOUZA et al., 2012) surface and subsurface o soil. Such fact is an indicative of aggregation quality (CARVALHO et al., 2010; SOUZA et al., 2012). On the other side, conventional systems, under intense soil inversion, tend to atomize aggregates, making them rounder (CREMON et al., 2009; SOUZA et al., 2012), thereby decreasing external surface roughness, as well as aggregate circumference.

Based on theabove, asoilmanagementsystemwith conservation practices combined with fertilization and concomitant agricultural gypsum application (CARDUCCI et al., 2014a, 2014b; SERAFIM et al., 2011, 2013a, 2013b) can beneficially contribute in morphometric attributes of soil aggregates (size and structural arrangement). Thus, this research aimed at evaluating morphometric attributes of aggregates from a Inceptisol, after one year and a half of coffee farming (Coffea arabica L.) within the region of Alto São Francisco (MG), Brazil, under conservationist system of soil management.

\section{Material and Methods}

The study was carried out at a commercial coffee crop area, under cultivation for one year and a half, which belongs to Empresa Agropecuária Piumhí (an agricultural business), located in the city of Vargem Bonita - MG, Brazil, within the vicinity of São Francisco River headwaters. The local climate is classified as Cwa type by Köppen's classification. It has annual mean rainfall of $1,344 \mathrm{~mm}$ and mean temperature of $20.7^{\circ} \mathrm{C}$, with hot and humid summers and a well-defined dry season from May to September (winter) (MENEGASSE et al., 2002). According to Embrapa (2013), the soil is classified as a typic dystrophic ( $\mathrm{Tb}$ ) Haplic Inceptisol (CXbd), with clayey texture and developed under siltstones (Table 1). 
On the basis of the Brazilian System of Land Use Capability (LEPSCH et al., 1991), the soil under study was classified by Serafim et al. (2013b) as belonging to a VIe-1, s-1-3-5, C-1 class, which stands for slope limitations (e-1), small effective depth (s -1), high amount of gravels (s-3), low base saturation (s-5) and prolonged drought (c-1). Lands fitting within this capacity class are suitable for restricted use as grazing and reforestation (LEPSCH et al., 1991).

Table 1. Physical characterization of the "A" and "Bi" horizons of a CXbd.

\begin{tabular}{|c|c|c|c|c|}
\hline $\mathrm{Hz}^{1}$ & Soil depth & Silt & Clay & Sand \\
\hline & ...m... & & $\mathrm{g} \mathrm{kg}^{-1}$ & $\ldots$ \\
\hline A & $0-0.1$ & 180 & 570 & 250 \\
\hline $\mathrm{Bi}$ & $0.1-0.31$ & 190 & 590 & 220 \\
\hline
\end{tabular}

${ }^{1} \mathrm{~Hz}$ : horizon. Adapted from Serafim et al. (2013b).

However, some authors as Severiano et al. (2009) and Serafim et al. (2011) have been demonstrating that adequate management with conservationist techniques, as crop residue maintenance, terrace among others, changes land plots under limited use into other uses, improving crop production and farmers' income. This way, even though the land area has limitations, when using the premises of the conservationist soil management under study, growers have been observed a successful development of coffee plantations and have reached high grain yields (SERAFIM et al., 2011, 2013b) without impairing soil conservation.

The current system has been carried out following prerequisites that request a conventional soil preparation initially and, posteriorly, soil and water conservationist techniques (SERAFIM et al., 2013a, 2013b). The area under study was prepared within July to August of 2008; plowing and two harrowings were made, and after each harrowing, $4 \mathrm{Mg} \mathrm{ha}^{-1}$ of lime (16-17\% $\left.\mathrm{MgO}\right)$ and $2 \mathrm{Mg} \mathrm{ha}^{-1}$ of gypsum were incorporated into the entire area.

In the second fortnight of October 2008, coffee seedlings were planted (Coffea arabica L.) using Catucaí Amarelo cultivar, within a semi-dense spacing of $2.50 \times 0.65 \mathrm{~m}$. Planting furrows were plowed by a spade-fertilizer machine that digs up to $0.60 \mathrm{~m}$ depth and $0.50 \mathrm{~m}$ wide, then mixing lime and fertilizers along the furrow extension. Two $\mathrm{Mg}$ ha-1 of dolomitic limestone (16-17\% $\mathrm{MgO}$ ) and $220 \mathrm{~g} \mathrm{~m}^{-1}$ of 08-44-00 mineral fertilizer with $1.5 \% \mathrm{Zn}$ and $0.5 \% \mathrm{~B}$ were applied into the planting furrows, aiming at fertilizing from 0.0 to $0.60 \mathrm{~m}$ of soil depth. Three months after planting, a further gypsum dose of $7.0 \mathrm{~kg} \mathrm{~m}^{-1}\left(28 \mathrm{Mg} \mathrm{ha}^{-1}\right)$ was used, as recommended by consultants and farmers for such management system, as described in Serafim et al. (2011); it was spread over soil surface (without incorporation) and along cultivation line (SILVA et al., 2014).

Brachiaria decumbens (Syn Urochloa) was sown in September of 2008, before coffee planting. After the grass reaches $0.5 \mathrm{~m}$ height, interlines were plowed at $0.1 \mathrm{~m}$ depth and the vegetal material removed was mixed back to soil and released near coffee trunks, performing a ridging. This ridging covers supplementary gypsum applied to the coffeetree line (SERAFIM et al., 2011). It is important to mentions that the grass was periodically hoed and remaining left on planting lines. In the first year after planting, it was applied $100 \mathrm{~kg} \mathrm{ha}^{-1}$ of ammonium nitrate over total area. Yet in the second, aiming at improving cut material yield and organic matter increment, the soil covered with the grass (interlines) received $600 \mathrm{~kg} \mathrm{ha}^{-1} \mathrm{~K}_{2} \mathrm{O}$ into four fractional applications throughout the year (SILVA et al., 2014). 
For chemical characterization, composite 2). It was carried out in all studied environments samples (40) from each soil layer (A, Bi) of the (planting line, interlines with brachiaria after 1.5 Inceptisol were performed using a Dutch auger in years of management and Cerrado native vegetation zigzag path sampling over the entire area (Table - grassland).

Table 2. Chemical characterization in a Inceptisol under Native Cerrado, Interlines with brachiaria and Crop line (coffee rows) after 1.5 years of management system implementation.

\begin{tabular}{ccccccccccccc}
\hline Managements & $\mathrm{Hz}$ & $\mathrm{pH}$ & $\mathrm{K}$ & $\mathrm{P}$ & $\mathrm{Ca}^{2+}$ & $\mathrm{Mg}^{2+}$ & $\mathrm{Al}^{3+}$ & $\mathrm{H}+\mathrm{Al}$ & $\mathrm{SB}$ & $\mathrm{T}$ & $\mathrm{V}$ & $\mathrm{m}$ \\
\hline & & $\left(\mathrm{H}_{2} 0\right)$ & \multicolumn{2}{c}{$\ldots \mathrm{mg} \mathrm{dm}^{-3} \ldots$} & & $\ldots \ldots \ldots \ldots \ldots \ldots . . \mathrm{cmol}_{\mathrm{c}} \mathrm{dm}^{-3} \ldots \ldots \ldots \ldots \ldots \ldots$. & $\ldots \ldots \ldots \ldots \ldots \ldots \ldots$ \\
Native Cerrado & $\mathrm{A}$ & 4.9 & 55 & 0.9 & 0.2 & 0.1 & 2.4 & 10.3 & 0.4 & 10.7 & 4.0 & 85 \\
& $\mathrm{Bi}$ & 4.7 & 81 & 1.2 & 0.2 & 0.1 & 3.5 & 15.1 & 0.5 & 15.6 & 3.0 & 87 \\
Interlines & $\mathrm{A}$ & 5.3 & 259 & 2.3 & 3.3 & 1.4 & 0.8 & 5.0 & 5.3 & 10.4 & 55 & 13 \\
(brachiaria) & $\mathrm{Bi}$ & 5.0 & 86 & 0.9 & 0.1 & 0.1 & 2.2 & 8.8 & 0.4 & 9.2 & 4.6 & 84 \\
Crop line (coffee & $\mathrm{A}$ & 4.3 & 232 & 6.5 & 3.4 & 0.3 & 0.5 & 8.8 & 4.29 & 13.09 & 32.8 & 10.4 \\
rows) & $\mathrm{Bi}$ & 4.6 & 110 & 0.56 & 2.3 & 0.1 & 0.7 & 5.05 & 2.68 & 7.73 & 34.7 & 20.7 \\
\hline
\end{tabular}

Hz: Soil horizons, $\mathrm{pH}$ : hydrogen potential, $\mathrm{K}$ : potassium, P: phosphorus, Mg: magnesium, Al: aluminum, Ca: calcium, SB: sum of bases, T: CEC at pH 7, V: base saturation. Adapted from Serafim et al. (2013b).

The completely randomized design in a split plot scheme was carried out in which plots accounted for the treatments. These consisted of Inceptisol under coffee trees (crop line), Inceptisol under brachiaria (interlines) and Inceptisol under native vegetation (Cerrado). Yet subplots accounted for sampling depths: $0.0-0.05 ; 0.05-0.20 ; 0.20-0.40$ and 0.40-0.80 $\mathrm{m}$, in three replications. Three trenches were randomly opened longitudinally to the coffee planting line, in interlines and in the area under grassland (control), which were collected soil blocks of $0.10 \times 0.10 \times 0.05 \mathrm{~m}$ with preserved structure.

As noted by Silva et al. $(2013,2014)$ in areas of dystrophic Red Latosol (Oxisol) under the same management system, both gypsum as organic matter are directly related to soil aggregation, since they change the chemical balance. Thus, at the same locations where samples were removed for aggregate study (planting line and interline as well as under native vegetation), three samples were collected deformed samples at 0.00 to $0.20 \mathrm{~m}$ (Hz A) and 0.40 to $080 \mathrm{~m}$ (Hz Bi) depths for organic matter and exchangeable calcium measurements.

Soil blocks were gently broken into smaller aggregates (keeping the original structure), air-dried and passed through a sieve set, in which meshes ranged from 4.76 to $9.52 \mathrm{~mm}$. Particles retained in the smaller mesh were used for stability tests in water and for 2D digital imaging.

Imaging was performed in three replications from each soil block at all depths assessed. Each image is composed of 60 randomly selected aggregates. This way, 6,480 aggregates were evaluated (4 depths x 3 treatments x 3 replications x 3 images of 60 aggregates per level combinations). Image acquisition was made through a flatbed scanner at 300 dpi resolution, which is recommended for this analysis type (VIANA et al., 2004). They were processed and quantified via Quantoporo software (VIANA et al., 2004), which has the ability of processing and analyzing morphological characteristics over an object surface, in general, in two dimensions (2D).

Firstly, we selected a suitable color channel, in this case RGB (red, green and blue) for pre-processing. Once RGB image was obtained, it underwent image cleaning by median filters that change each pixel value into median value of neighboring pixels. The main purpose of this process is to reduce isolated 
pixels, i.e., noise and devices that cause distortions particularly in the perimeter measurements (CREMON et al., 2009, 2011; SOUZA et al., 2012). It is noteworthy to mention that images with and without filter use are performed until reaching a deviation among 10 pairs of values lower than 0.05 (At a 95\% confidence interval); this value is an indicative that the image is near the real image. All images were still converted into a binary code [0,1], i.e., constituted by black and white colors through the manual thresholding command (Threshold) of the software (CREMON et al., 2009).

Analyzed characteristics were: 1. Area - Ar $\left(\mathrm{cm}^{2}\right)$ : It is measured with the number of pixels within the polygon, indicating soil aggregation state (aggregate formation capability). Area measurements are pixel counting of an image after its transformation into a black and white image; thus, each pixel area is a function of input image resolution. A 300 dpi image has an area of 0.0071684 $\mathrm{mm}^{2}$ per pixel (VIANA, 2001); 2. Perimeter - Per (cm): length of the projection of the aggregate external limit (CREMON et al., 2011; OLSZEVSKI et al., 2004); 3. Aspect (Asp) provides results of 0 or 1 , and the higher the value the greater the degree of rounding (CREMON et al., 2011; OLSZEVSKI et al., 2004); 4. Roughness (Rou): is a measure that varies with aggregate external surface roughness which expresses grooves on aggregate, being that flatter surfaces have value near 1 (CREMON et al., 2011); 5. Ferret diameter - FD $\left(\mathrm{cm}^{2}\right)$ : diameter of a circle with the same area of the object calculated by the formula:

$$
\sqrt{\left(4 \frac{A r}{\pi}\right)}
$$

and 6. Compactness - Cmp (cm): provides a measurement of the object roughness, being dependent on the length of the major axis.

It varies from 0 to 1 , and if equals to 1 , the aggregate is perfectly circular. It is calculated by the following formula:

$$
\sqrt{\left(4 \frac{A r}{\pi}\right)} / \text { LMA }
$$

(wherein: LMA is the length of the major axis) as described by Olszevski et al. (2004).

It is emphasized that area, perimeter, aspect and roughness are measured and obtained by the calculation algorithm of the Quantoporo, which is evaluated pixel by pixel, producing data matrixes. Thus, like all variables, in which calculation depends on Ar and Per values, it has its result influenced by image processing procedures, to automate $2 \mathrm{D}$ image analysis and obtain other morphometric data, calculation formulas for $\mathrm{Cmp}$ and $\mathrm{DF}$ were also inserted into the Quantoporo algorithm.

Perimeter and area measures are affected by image resolution; so, this way, before image analysis, Quantoporo software was calibrated: 10 geometric figures of known dimensions (squares, circles) were digitalized at a resolution of 300 dpi and processed according to the procedures described above. Generated data were compared to the actual dimensions of the standard image, and we considered the quality of program calibration, when data deviations of area and perimeter measured by the program and those calculated by the standard image did not exceed $0.05 \mathrm{~mm}$ (95\% confidence interval).

Aggregate stability determination in water followed procedures described by Kemper and Chepil (1965) to achieve aggregation indexes: 1Percentage of aggregates retained in each sieve, 2mean weight diameter (MWD), and 3 - geometric mean diameter (GMD).

First, we performed a variance analysis to detect influences of management system and sampling depths on morphometric characteristics. The analysis was carried to detect effects of both each factor and their interaction. Since the interaction had no significant effect, data breakdown within each treatment or soil management was performed (line, interline and native vegetation). We conducted 
also a variance analysis to test the effect of soil preparation on aggregate morphology throughout the soil profile, as the planting line received a plowing up to a depth of $0.60 \mathrm{~m}$. For this, we used a completely randomized design with 4 depths and 9 replications depths (3 blocks per depth $\mathrm{x} 3$ images of 60 aggregates). Means were compared when appropriate by the Scott-Knott test at nominal level of 5\% probability through SISVAR application (FERREIRA, 2011). Sigma Plot was used for 11.0 Pearson correlation test.

\section{Results and Discussion}

Soil aggregates under the management system have superior morphometric characteristics to the aggregates under Native Cerrado (Table 3). Both in line and interlines, the variables indicate a small degree of progress in aggregate size (larger values of Ar Per and FD), having a more striated surface (larger Rou) (CREMON et al., 2009, 2011; SOUZA et al., 2012). Such fact favors porosity and a greater contact area of these aggregates with soil solution and atmosphere (SOUZA et al., 2012).

Table 3. Mean values of area (Ar), perimeter (Per), aspect (Asp), roughness (Rou), compactness (Cmp) and Ferret diameter (FD) for managements: Native Cerrado, Interlines with brachiaria and Crop line (coffee rows).

\begin{tabular}{lcccccc}
\hline Managements & $\mathrm{Ar}$ & Per & Asp & Rou & Cmp & FD \\
\hline & $. . \mathrm{cm}^{2} .$. & $. . \mathrm{cm} .$. & & & $. . \mathrm{cm} .$. & $. . \mathrm{cm}^{2} .$. \\
Native Cerrado & $0.30 \mathrm{c}$ & $3.74 \mathrm{~b}$ & $0.81 \mathrm{a}$ & $0.18 \mathrm{~b}$ & $0.004 \mathrm{~b}$ & $0.35 \mathrm{c}$ \\
Interlines (brachiaria) & $0.51 \mathrm{~b}$ & $7.76 \mathrm{a}$ & $0.81 \mathrm{a}$ & $0.37 \mathrm{a}$ & $0.009 \mathrm{a}$ & $0.78 \mathrm{a}$ \\
Crop line (coffee rows) & $0.63 \mathrm{a}$ & $7.34 \mathrm{a}$ & $0.76 \mathrm{~b}$ & $0.25 \mathrm{~b}$ & $0.04 \mathrm{a}$ & $0.51 \mathrm{~b}$ \\
\hline
\end{tabular}

Means followed by same letter in the column do not differ by the Scott-Knott test $(p<0.05)$.

Nevertheless, even under Native Cerrado conditions or conservationist cultivation, the aggregates showed a trend to round shapes (Asp $=1$ ). Rounding is a property that interferes with aggregate transportation phase by erosive agents. Therefore, the aspect variable can be used as a predictor for transportation capacity via water (SOUZA et al., 2012). As stated by Carvalho et al. (2010) and Cremon (2007), smaller aggregates are more elliptical $(0.5<$ Asp $<0.70)$ and easily transported over long distances, while larger aggregates (Ar and FD) and squared ones $(0.73<$ Asp $<0,82$ ) are further stretched, and have greater resistance to transportation by water (CARVALHO et al., 2010; SOUZA et al., 2012).

Rounder aggregates are commonly observed under conventional management systems; the reduced roughness of these aggregates comes from the action of farming implements, such as disk harrow, that break aggregate edges (OLSZEVSKI et al., 2004; SOUZA et al., 2012).
Squared aggregates were prevalent, but with round angles in the edges $(0.73<$ Asp $<0.82)$ (CREMON et al., 2011). Square, polyhedron and round formats (Asp, Rou) and dimensions (Ar, Per, FD) of aggregates may be influenced by soil chemical and mineralogical composition (SOUZA et al., 2012). In studies developed by Melo et al. (2008), greater amounts of gibbsite, goethite e hematite favored increased aggregate areas in an oxidic Latosol (Oxisol), once they neutralize kaolinite negative charges, what contributes to aggregate expansion.

Nonetheless, there are no studies relating mineralogy to soil aggregate morphometry in Inceptisol. Under no circumstances, this research suggests that after plowing to $0.60 \mathrm{~m}$ depth, which initiallycauses disruptionoflargersoilaggregates, has a major effect of kaolinitic mineralogy (RESENDE et al., 2014) in soil structural rearrangement over time. It gives the new aggregates a square shape, which is consistent with the block structure found 
in field. According to Melo et al. (2008), kaolinite predominance in clay fraction would favor a better fit of this mineral crystals inducing structure growth toward a single direction.

Aggregates with larger dimensions of Ar, Per and FD were found in soil under brachiaria (interline) and coffee (line). This fact might be related to large scale of organic matter (OM) and exchangeable calcium $\left(\mathrm{Ca}^{2+}\right)$ inputs promoted by this management system (Table 4). As already stressed about this system, the brachiaria plants grown in interlines had periodic cuts and later distribution of the residues over the cultivation line (coffee plants) (SERAFIM et al., 2011; SILVA et al., 2013). In this way, the decomposition of plant remains in both line and interline has positive effects on aggregate formation, and favors macroaggregate formation (Table 3).

Table 4. Mean values of soil organic matter (SOM) and calcium (Ca) in a Inceptisol under Native Cerrado and Crop line (coffee rows) after 1.5 years of management system implementation.

\begin{tabular}{lccc}
\hline Soil use & $\mathrm{Hz}$ & $\mathrm{SOM}(\%)$ & $\mathrm{Ca}\left(\mathrm{cmol}_{\mathrm{c}} \mathrm{dm}^{-3}\right)$ \\
\hline \multirow{2}{*}{ Native Cerrado } & $\mathrm{A}$ & 2.44 & 0.3 \\
& $\mathrm{Bi}$ & 0.65 & 0.1 \\
\multirow{2}{*}{ Crop line (coffee rows) } & $\mathrm{A}$ & 3.95 & 3.3 \\
& $\mathrm{Bi}$ & 3.30 & 2.3 \\
\hline
\end{tabular}

OBS. Samples collected at the same locations where the aggregates were sampled.

Confirming the findings of this study, Olszevski et al. (2004) and Cremon et al. (2011), who had studied the influence of different management systems on aggregate morphometry, observed larger aggregates in systems with a great organic matter input, when compared to those systems with intense farming practices and soil inversion.

Management systems with large organic matter input and no soil inversion, as no-tillage system, provide increment in size of aggregates (CREMON et al., 2009; SOUZA et al., 2012) and stability in water (CASTRO FILHO et al., 1998). These characteristics favor an increase in carbon stocks by physically protecting organic matter within soil aggregates (BAYER et al., 2004; COSTA JÚNIOR et al., 2012) against microbial activity, besides decreasing the availability of oxygen for oxidation processes of decomposition (BALESDENT et al., 2000).

In addition to the effect of OM from brachiaria residue, in planting lines can also be noted the effect of agricultural gypsum applied on soil surface. This product is a good source of exchangeable calcium
$\left(\mathrm{Ca}^{2+}\right)$, which under the dry climate conditions in Alto São Francisco, as shown by Ramos et al. (2013) in studies of chemical speciation, promote a slow release of this nutrient, but leading to relevant levels $\left(27 \mathrm{mmol}_{\mathrm{c}} \mathrm{dm}^{-3}\right)$ to promote clay flocculation and aggregate area increase, improving soil aggregation (CREMON et al., 2009; SOUZA et al., 2012). To confirm the $\mathrm{Ca}^{2+}$ contribution in soil aggregation, Silva et al. (2013) observed increased geometric diameter of aggregates in experimental areas of Latosols (Oxisols) that had received high doses of agricultural gypsum (7 and $28 \mathrm{Mg} \mathrm{ha}^{-1}$ ), whose

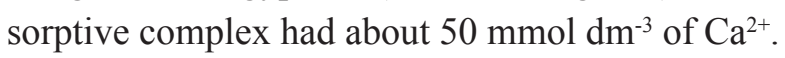

In accordance with Amaral et al. (2004), plant residue plays an important role by releasing lowmolecular-weight organic acids, which are able to form organic complexes with aluminum, calcium and magnesium in soil surface layer. Therefore, it is suggested that the higher OM content of management systems that received high doses of gypsum are related to a higher content of $\mathrm{Ca}^{2+}$, and calcium and organic matter interaction promotes improvements in soil aggregation properties. 
Nevertheless, as pointed out by Silva et al. (2013), there is still a lack of information on crop residue effects in the Brazilian literature, when remained on soil surface under different management systems, particularly with regard to method standardization to evaluate the effects of these residues solely or with gypsum and / or limestone.

In CXbd under brachiaria (interline) and coffee (line), rounder aggregates (Cmp) were found compared to Native Cerrado (Table 3). Although presenting the highest values of $\mathrm{Cmp}$, they are still regarded as very low, and values near 1 are indicative of structural deterioration (OLSZEVSKI et al., 2004).

There was no significant difference for morphometric characteristics between Native Cerrado and coffee interlines among all soil depths (Table 5). It may be due to the lack of anthropogenic action in cerrado environment and non-adoption of primary and secondary tillage practices in growing lines (SERAFIM et al., 2011), besides the use of animal traction for cultivation (CARDUCCI et al., 2014a), which minimizes the load on soil surface as they move over a dense vegetation cover of brachiaria.

Table 5. Mean values of area (Ar), perimeter (Per), aspect (Asp), roughness (Rou), Ferret diameter (DF) and compactness $(\mathrm{Cmp})$ at different depths of $\mathrm{CXbd}^{1}$ under Native Cerrado, Interlines with brachiaria and Crop line (coffee rows).

\begin{tabular}{|c|c|c|c|c|c|c|}
\hline $\begin{array}{l}\text { Soil depth } \\
\text { (m) }\end{array}$ & $\begin{array}{l}\mathrm{Ar} \\
. . \mathrm{c}\end{array}$ & $\begin{array}{l}\text { Per } \\
\text { n... }\end{array}$ & Asp & Rou & $\begin{array}{c}\mathrm{FD} \\
. . \mathrm{cm}^{2} . .\end{array}$ & $\begin{array}{l}\text { Cmp } \\
\text {..cm... }\end{array}$ \\
\hline \multicolumn{7}{|c|}{ Interlines (brachiaria) ${ }^{\mathrm{ns}}$} \\
\hline $0.0-0.05$ & $0.50 \mathrm{a}$ & $5.31 \mathrm{a}$ & $0.81 \mathrm{a}$ & $0.28 \mathrm{a}$ & $1.00 \mathrm{a}$ & $0.00 \mathrm{a}$ \\
\hline $0.05-0.20$ & $0.60 \mathrm{a}$ & $6.42 \mathrm{a}$ & $0.79 \mathrm{a}$ & $0.35 \mathrm{a}$ & $0.87 \mathrm{a}$ & $0.00 \mathrm{a}$ \\
\hline $0.20-0.40$ & $0.52 \mathrm{a}$ & $9.75 \mathrm{a}$ & $0.84 \mathrm{a}$ & $0.11 \mathrm{a}$ & $0.58 \mathrm{a}$ & $0.00 \mathrm{a}$ \\
\hline $0.40-0.80$ & $0.51 \mathrm{a}$ & $8.20 \mathrm{a}$ & $0.78 \mathrm{a}$ & $0.15 \mathrm{a}$ & $0.74 \mathrm{a}$ & $0.01 \mathrm{a}$ \\
\hline \multicolumn{7}{|c|}{ Crop line (coffee rows)* } \\
\hline $0.0-0.05$ & $0.70 \mathrm{a}$ & $5.79 \mathrm{~b}$ & $0.77 \mathrm{a}$ & $0.36 \mathrm{a}$ & $0.84 \mathrm{a}$ & $0.00 \mathrm{a}$ \\
\hline $0.05-0.20$ & $0.62 \mathrm{~b}$ & $5.11 \mathrm{~b}$ & $0.76 \mathrm{a}$ & $0.35 \mathrm{a}$ & $0.97 \mathrm{a}$ & $0.01 \mathrm{a}$ \\
\hline $0.20-0.40$ & $0.65 \mathrm{~b}$ & $6.71 \mathrm{~b}$ & $0.81 \mathrm{a}$ & $0.28 \mathrm{a}$ & $0.74 \mathrm{~b}$ & $0.00 \mathrm{a}$ \\
\hline $0.40-0.80$ & $0.61 \mathrm{~b}$ & $10.2 \mathrm{a}$ & $0.73 \mathrm{a}$ & $0.11 \mathrm{~b}$ & $0.62 \mathrm{~b}$ & $0.00 \mathrm{a}$ \\
\hline \multicolumn{7}{|c|}{ Native Cerrado ${ }^{\text {ns }}$} \\
\hline $0.0-0.05$ & $0.28 \mathrm{a}$ & $3.6 \mathrm{a}$ & $0.81 \mathrm{a}$ & $0.11 \mathrm{a}$ & $0.35 \mathrm{a}$ & $0.00 \mathrm{a}$ \\
\hline $0.05-0.20$ & $0.23 \mathrm{a}$ & $3.0 \mathrm{a}$ & $0.84 \mathrm{a}$ & $0.12 \mathrm{a}$ & $0.33 \mathrm{a}$ & $0.00 \mathrm{a}$ \\
\hline $0.20-0.40$ & $0.29 \mathrm{a}$ & $3.0 \mathrm{a}$ & $0.81 \mathrm{a}$ & $0.14 \mathrm{a}$ & $0.39 \mathrm{a}$ & $0.00 \mathrm{a}$ \\
\hline $0.40-0.80$ & $0.38 \mathrm{a}$ & $5.0 \mathrm{a}$ & $0.79 \mathrm{a}$ & $0.08 \mathrm{a}$ & $0.34 \mathrm{a}$ & $0.00 \mathrm{a}$ \\
\hline
\end{tabular}

${ }^{1} \mathrm{CXbd}$ : typic dystrophic (Tb) Haplic Inceptisol; ${ }^{\text {ns }}$ not significant; * Significant $(\mathrm{P}<0.05)$. Means followed by same letter in the column for each land management do not differ by the Scott-Knott test $(\mathrm{p}<0.05)$.

In interlines, the morphometric variables Cmp, FD and Ar could express the negative effect of machine traffic (harvesting, spraying, mowing and others) on soil structure. However, these values, Cmp $(<0.5)$, FD $(>0.5)$ and Rou $(<0.40)$ showed that animal traction and brachiaria management have possibly overcome the limitations from cultivation activities, favoring the absence of flat, compact and round aggregates, which are indicative of soil degradation.

Moreover, this fact is possibly related to the action of a dense fascicular root system. Lawns with fine and abundant roots, when well managed, are able to break compacted and hardened layers of soil (SEVERIANO et al., 2009). 
In planting line, where soil was turned, the variables Rou, Ar, Per and FD differed among depths (Table 5). At 0.0-0.05 $\mathrm{m}$ depth, due to the great amount of brachiaria residue, the aggregate had higher surface area what is very important in order that the presence of larger aggregates favors soil macroporosity (SOUZA et al., 2012). The macroporosity enables root system development, enhances hydrodynamics, as well as ensures aeration uniformity (CREMON et al., 2009) due to irregular contact between an aggregate and another, and thus having a better distribution of empty spaces. Furthermore, aggregates are more edgy, irregularly shaped and grooved surfaces $($ Rou $<0.5)$ up to a depth of $0.40 \mathrm{~m}$, which highlight the effect of soil tillage associated with the mineralogy of the CXbd (RESENDE et al., 2014), providing a block structure formation. This geometric irregularity and porosity (biopores) were visible in the field.

It is also observed that $\mathrm{Ca}^{2+}$ from inputs (gypsum and limestone), applied during the crop establishment, has favored the development of coffee plant roots throughout the soil profile (CARDUCCI et al., 2014a, 2014b). Plant root distribution within the soil has great influence on aggregate formation and stabilization, the mechanical force produced by root growth gathers the mineral particles (FOLONI et al., 2006), as well as releases exudates and organic polysaccharides (COSTA JÚNIOR et al., 2012). These substances form sticky nets that join soil particles together with the microaggregates, originating larger clusters called macroaggregates (aggregates with higher Ar, Per and FD) as observed in this study. It is also important to mention that small aggregates promote soil compaction, hindering root development (SOUZA et al., 2012).

Rou larger values and smaller of Per were detected at the depths of 0.0-0.05, 0.0-0.20 and 0.20$0.40 \mathrm{~m}$ in planting lines. Rou values at layers with turned soil ( 0 to $0.40 \mathrm{~m}$ ) were inferior to 0.40 , which typifies aggregates of grooved or rough surfaces (CREMON et al., 2011). These findings make it clear that the set of practices used in the evaluated management system contributed to beneficial changes in the structure of the Inceptisol, forming more edgy aggregates with groovy surfaces.

These results are related to the practice of deep tillage, performed before crop implantation, causing the disruption of soil aggregates, which is justified since there is an incorporation of fertilizers and limestone, besides increasing the porosity of this compacted soil or naturally dense, enabling the development of the root system (SERAFIM et al., 2013a). Over time, there is an increase in organic matter content, associated with rising calcium levels; this way, a reorganization of soil structure is expected in a long term, as well as the formation of aggregates with morphometric characteristics (edgy particles and groovy surfaces) that are more advantageous to a good soil structure.

Correlation analyzes were performed between morphometric characteristics and standard aggregation observed in the planting line (Table 6). Negative correlation was found $(r=-0.63)$ between GMD and Per. A strong negative correlation ( $\mathrm{r}$ $=-0.78$ ) between aggregates $<105 \mathrm{~mm}$ (very fine sand) and Rou was already expected, since smaller aggregates have round and flat aspect without external grooves. Aggregates with these characteristics express the early degradation of soil structure and their presence in superficial layers is undesirable, once they provide a surface sealing and greater loss of soil by erosion.

It was observed a positive correlation between aggregates $>2.00 \mathrm{~mm}, \mathrm{MWD}$ and GMD with FD and Rou. Edgy and bumpy aggregates have higher GMD. The arrangement of these aggregates favors a structural organization that provides better spaces (macropores) for the development of the coffee roots. 
Table 6. Correlation coefficients between aggregate size classes, MWD, GMD and morphometric characteristics of $\mathrm{CXbd}^{1}$ evaluated at different depths of Crop line.

\begin{tabular}{lcccc}
\hline Aggregate & Per & Asp & FD & Rou \\
\hline$>2,00 \mathrm{~mm}$ & -0.563 & 0.224 & $0.629^{*}$ & $0.602^{*}$ \\
$<105 \mathrm{~mm}$ & $0.671^{*}$ & -0.457 & $-0.657^{*}$ & $-0.788^{* *}$ \\
MWD & -0.576 & 0.235 & $0.637^{*}$ & $0.613^{*}$ \\
GMD & $-0.633^{*}$ & 0.273 & $0.665^{* *}$ & $0.797^{* * *}$ \\
\hline
\end{tabular}

${ }^{1} \mathrm{CXbd}$ : typic dystrophic $(\mathrm{Tb})$ Haplic Inceptisol * significant $\mathrm{P}<0.05$, ** significant $\mathrm{P}<0.01, * * *$ significant $\mathrm{P}<0.001$.

Upon field observations, a high concentration of these aggregates was verified at a depth of $0.40 \mathrm{~m}$, as well as lots of roots between and within aggregates. This suggests that the management practices has allowed a better root system development in the soil. It is noted that under natural conditions, Inceptisols from pelitic rocks are compact even at surface layers (OLIVEIRA, 1993).

The negative correlation between FD and depth (Figure 1) is consistent, in view of the lowest structuring in subsurface horizons, highlighting that soil in this plot has horizon $\mathrm{C}$ at a depth of $0.6 \mathrm{~m}$.

Figure 1. Correlation and linear regression between Ferret diameter and depths in Crop line.

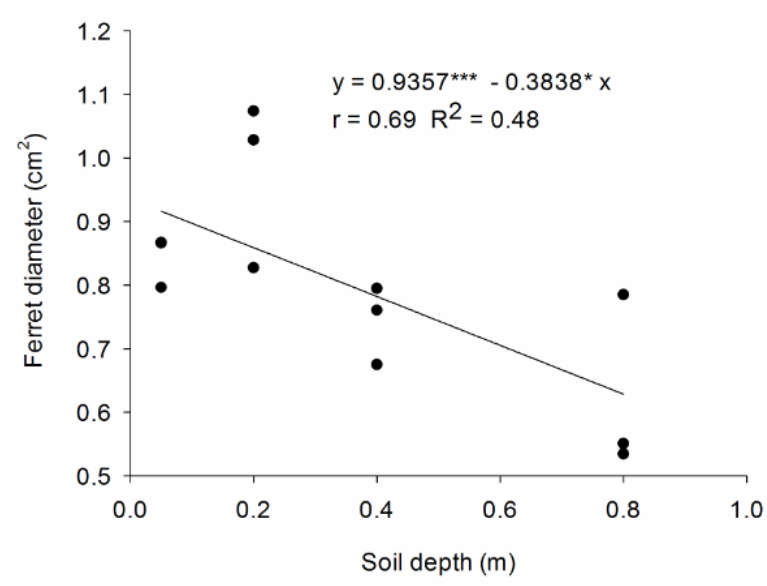

The high FD values (Table 5) found at depths of 0.0-0.05 $\mathrm{m}$ and $0.05-0.20 \mathrm{~m}$ assist in justifying the plant vigor in this soil, under the management studied. It should be noted that under natural conditions, the CXbd has many chemical and hydro-physical limitations (SERAFIM et al., 2013a, 2013b), which in a preliminary analysis would restrict its inclusion in agricultural use.

The positive results in terms of aggregation in the crop line have probably conditioned improvements in soil-air-water relationship, favoring root growth at deeper depths, and therefore greater soil exploration for water and nutrients (CARDUCCI et al., 2014a, 2014b; SERAFIM et al., 2011; SILVA et al., 2013, 2014).

\section{Conclusions}

The 2D image analysis detected morphometric changes on aggregates of $\mathrm{CXbd}$ under natural condition (Native Cerrado) and under the management system studied (line and interline); thus, it can be used as a diagnostic tool in studies of soil structural quality.

After one year and a half of cropping with coffee, improvements in soil aggregation were observed, by forming larger aggregates ( $>$ Ferret diameter) with more edgy external surface.

\section{Acknowledgements}

The authors want to thank the funding agencies of Fapemig, Cnpq and EMBRAPA Café for financial support, and the Empresa Agropecuária Piumhí for support to perform the study. 


\section{References}

AMARAL, A. S.; ANGHINONI, I.; DESCHAMPS, F. C. Resíduos de plantas de cobertura e mobilidade dos produtos da dissolução do calcário aplicado na superfície do solo. Revista Brasileira de Ciência do Solo, Viçosa, MG, v. 28, n. 1, p. 115-123, 2004.

BALESDENT, J.; CHENU, C.; BALABANE, M. Relationship of soil organic matterdynamics to physical protection and tillage. Soil and Tillage Research, Amsterdam, v. 53, n. 3-4, p. 215-230, 2000.

BAYER, C.; MARTIN-NETO, L.; MIELNICZUK, J.; PAVINATO, A. Armazenamento de carbono em frações lábeis da matéria orgânica de um Latossolo Vermelho sob plantio direto. Pesquisa Agropecuária Brasileira, Brasília, v. 39, n. 7, p. 677-683, 2004.

CARDUCCI, C. E.; OLIVEIRA, G. C.; CURI, N.; HECK, R. J.; ROSSONI, D. F. Scaling of pores in 3D images of Latosols (Oxisols) with contrasting mineralogy under conservation management system. Soil Research, Victoria, v. 52, n. 3, p. 231-243, 2014b.

CARDUCCI, C. E.; OLIVEIRA, G. C.; LIMA, J. M.; ROSSONI, D. F.; SOUZA, A. L.; OLIVEIRA, L. M. Distribuição espacial das raízes de cafeeiro e dos poros de dois Latossolos sob manejo conservacionista. Revista Brasileria de Engenharia Agrícola e Ambiental, Campina Grande, v. 18, n. 3, p. 270-278, 2014a.

CARVALHO, J. M.; CREMON, C.; MAPELI, N. C.; NUNES, M. C. M.; SILVA, W. M.; MAGALHÃES, W. A.; SANTOS, A. S. Análise micromorfométrica de agregados de um Latossolo Vermelho distroférrico sob diferentes sistemas de cultivo. Revista Agrarian, Dourados, v. 3, n. 10, p. 275-285, 2010.

CASTRO FILHO, C.; MUZILLI, O.; PODANOSCHI, A. L. Estabilidade dos agregados e sua relação com o teor de carbono orgânico num latossolo roxo distrófico, em função de sistemas de plantio, rotações de culturas e métodos de preparo das amostras. Revista Brasileira de Ciência do Solo, Viçosa, MG, v. 22, n. 3, p. 527-538, 1998.

COSTA JÚNIOR, C.; PÍCCOLO, M. C.; SIQUEIRA NETO, M.; CAMARGO, P. B.; CERRI, C. C.; BERNOUX, M. Carbono em agregados do solo sob vegetação nativa, pastagem e sistemas agrícolas no bioma cerrado. Revista Brasileira de Ciência do Solo, Viçosa, MG, v. 36, n. 4, p. 1311-1321, 2012.

CREMON, C. Levantamento dos atributos de um inceptisol influenciados por diferentes sistemas de cultivo de arroz no norte da Itália. 2007. Dissertação (Doutorado em Agronomia) - Universidade Federal da Grande Dourados, Dourados.
CREMON, C.; ROSA JÚNIOR, E. J.; SERAFIM, M. E.; ONO, F. B. Análise micromorfométrica de agregados de um Latossolo Vermelho distroférrico sob diferentes sistemas de manejo. Acta Scientiarum Agronomy, Maringá, v. 3, n. 1, p. 139-146, 2009.

CREMON, C.; SACCO, D.; GRIGNANI, C.; ROSA JÚNIOR, E. J.; MAPELI, N. C. Micromorfometria de agregados do solo sob diferentes sistemas de cultivo de arroz. Pesquisa Agropecuária Tropical, Goiânia, v. 41, n. 3, p. 370-377, 2011.

EMPRESA BRASILEIRA DE PESQUISA AGROPECUÁRIA - EMBRAPA. Embrapa solos. Sistema brasileiro de classificação de solos. 3. ed. Brasília: Embrapa, 2013. 353 p.

FERREIRA, D. F. SISVAR 5. 0. Sisvar: a computer statistical analysis system. Ciência e Agrotecnologia, Lavras, v. 35, n. 6, p. 1039-1042, 2011.

FOLONI, J. S. S.; LIMA, S. L. de; BÜLL, T. Crescimento aéreo e radicular da soja e de plantas de cobertura em camadas compactadas de solo. Revista Brasileira de Ciência do Solo, Viçosa, MG, v. 30, n. 1, p. 49-57, 2006.

KEMPER, W. D.; CHEPIL, W. S. Size distribution of aggregates. In: BLACK, C. A. Methods of soil analysis. Madison: American Society of Agronomy, 1965. p. 499510 .

LEPSCH, I. F.; BELLINAZZI JÚNIOR, R.; BERTOLINI, D.; ESPÍNDOLA, C. R. Manual para levantamento utilitário de meio físico e classificação de terras no sistema de capacidade de uso: $4^{\text {a }}$ aprox. Campinas: Sociedade Brasileira de Ciência do Solo, 1991. 175 p.

MELO, V. F.; MOURA, R.; TOLEDO, F. H.; LIMA, V. C.; GHIDIN, A. A. Morfologia de agregados de Latossolo Bruno e Vermelho do estado do Paraná, avaliada por imagens obtidas em scanner. Revista Brasileira de Ciência do Solo, Viçosa, MG, v. 32, n. 1, p. 85-99, 2008.

MENEGASSE, L. N.; GONÇALVES, J. M.; FANTINEL, L. M. Disponibilidades hídricas na Província cárstica de Arcos-Pains-Doresópolis, Alto São Francisco, Minas Gerais, Brasil. Revista Águas Subterrâneas, São Paulo, v. 16, n. 16, p. 9-21, 2002.

OLIVEIRA, G. C. Cambissolos da microrregião Campos da Mantiqueira, MG: caracterização fisicico-hídrica e interpretação para manejo. 1993. Dissertação (Mestrado em Ciência do Solo) - Universidade Federal de Lavras, Lavras.

OLSZEVSKI, N.; COSTA, L. M.; FERNANDES FILHO, E. I.; RUIZ, H. A.; ALVARENGA, R. C.; CRUZ, J. C. Morfologia de agregados do solo avaliada por meio de análise de imagens. Revista Brasileira de Ciência do Solo, Viçosa, MG, v. 28, n. 5, p. 901-909, 2004. 
RAMOS, B. Z.; VAZ, J. P. V. F.; LIMA, J. M.; SERAFIM, M. E.; BASTOS, A. R. R.; GUIMARÃES, P. T. G.; COSCIONE, A. R. Doses de gesso em cafeeiro: influência nos teores de cálcio, magnésio, potássio e pH na solução de um Latossolo Vermelho distrófico. Revista Brasileira de Ciência do Solo, Viçosa, MG, v. 37, n. 4, p. 1018-1026, 2013.

RESENDE, M.; CURI, N.; REZENDE, S. B.; CORRÊA, G. F. Pedologia: base para distinção de ambientes. 6. ed. Lavras: Universidade Federal de Lavras, 2014. 378 p.

SERAFIM, M. E.; OLIVEIRA, G. C.; CURI, N.; LIMA, J. M.; GUIMARÃES, P. T. G.; LIMA, V. M. P. Potencialidades e limitações de uso de Latossolos e Cambissolos, sob sistema conservacionista em lavouras cafeeiras. Bioscience Journal, Uberlândia, v. 29, n. 5, p. 1640-1652, 2013b.

SERAFIM, M. E.; OLIVEIRA, G. C.; OLIVEIRA, A. S.; LIMA, J. M.; GUIMARÃES, P. T. G.; COSTA, J. C. Sistema conservacionista e de manejo intensivo do solo no cultivo de cafeeiros na região do Alto São Francísco, MG: um estudo de caso. Bioscience Journal, Uberlândia, v. 27, n. 6 , p. 964-977, 2011.

SERAFIM, M. E.; OLIVEIRA, G. C.; VITORINO, A. C. T.; SILVA, B. M.; CARDUCCI, C. E. Qualidade física e intervalo hídrico ótimo em Latossolo e Cambissolo, cultivados com cafeeiro, sob manejo conservacionista do solo. Revista Brasileira de Ciência do Solo, Viçosa, MG, v. 37, n. 3, p. 733-742, 2013 a.

SEVERIANO, E. C.; OlIVEIRA, G. C.; CURI, N.; DIAS JÚNIOR, M. S. Potencial de uso e qualidade estrutural de dois solos cultivados com cana-de-açúcar em Goianésia (GO). Revista Brasileira de Ciência do Solo, Viçosa, MG, v. 33, n. 1, p. 159-168, 2009.
SILVA, É. A.; OLIVEIRA, G. C.; CARDUCCI, C. E.; SILVA, B. M.; OLIVEIRA, L. M.; COSTA, J. C. Increasing doses of agricultural gypsum, aggregate stability and organic carbon in Cerrado Latosol under coffee crop. Revista Ciências Agrárias, Belém, v. 56, n. 1, p. 25-32, 2013.

SILVA, É. A.; OLIVEIRA, G. C.; SIVA, B. M.; CARDUCCI, C. E.; AVANZI, J. C.; SERAFIM, M. E. Aggregate stability by the high energy moisture characteristic method in an oxisol under differentiated management. Revista Brasileira de Ciência do Solo, Viçosa, MG, v. 38, n. 5, p. 1633-1642, 2014.

SOUZA, F. R.; ROSA JÚNIOR, E. J.; FIETZ, C. R.; PELLIN, D. M. P.; BERGAMIN, A. C.; GELAIN, E.; ROSA, Y. B. C. J. Morphology and stability of aggregates of an Oxisol according to tillage system and gypsum application. Revista Ceres, Viçosa, MG, v. 59, n. 6, p. 859-866, 2012.

VIANA, J. H. M. Análise de imagens micropedológicas com utilização do programa Quantporo e sua aplicação ao estudo de umedecimento e secagem em amostras de Latossolos. 2001. Dissertação (Mestrado em Solos e Nutrição de Plantas) - Universidade Federal de Viçosa, Viçosa, MG.

VIANA, J. H. M.; FERNANDES FILHO, E. I.; SCHAEFER, C. E. G. R. Efeitos de ciclos de umedecimento e secagem na reorganização da estrutura microgranular de Latossolos. Revista Brasileira de Ciência do Solo, Viçosa, MG, v. 28, n. 1, p. 11-19, 2004. 